Österreichische Akademie der Wissenschaften / Austrian Academy of Sciences AAS WORKING PAPERS IN SOCIAL ANTHROPOLOGY

Volume 19

\title{
Najwa Adra \\ TRIBAL MEDIATION IN YEMEN AND ITS IMPLICATIONS TO DEVELOPMENT
}

Irivilutin

Band 19

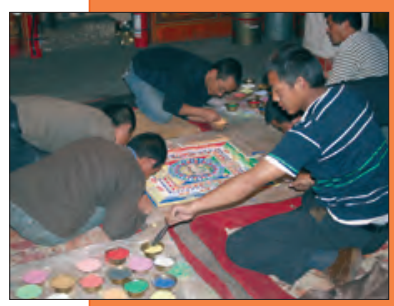




\section{AAS Working Papers in Social Anthropology / \\ ÖAW Arbeitspapiere zur Sozialanthropologie}

ISSN: 1998-507X

doi: $10.1553 /$ wpsa19

ISBN: 978-3-7001-6944-4

Wien 2011

\section{Editors / Herausgeber:}

Andre Gingrich \& Guntram Hazod

(C) Institut für Sozialanthropologie

Zentrum Asienwissenschaften und Sozialanthropologie

Österreichische Akademie der Wissenschaften

Apostelgasse 23

A-1030 Wien

Fax: 01/ 51581-6450

E-Mail: sozialanthropologie@oeaw.ac.at 


\title{
TRIBAL MEDIATION IN YEMEN AND ITS IMPLICATIONS TO DEVELOPMENT**
}

\author{
NAJWa AdRa
}

\section{Introduction}

An international phenomenon that has captured the interest of scholars and international development organizations is a continued tendency to resolve conflict through indigenous methods rather than in state courts (Chirayath et al.; Corrin Care 2000; Syria-News.com; UNDP). In Yemen, as in countries as diverse as Kenya and the Solomon Islands, traditional justice is often perceived as familiar, transparent, and participatory. Its focus is reconciliation rather than punishment (Dempsey and Coburn 2010; Dimitrijevic 2006). Specifically in Yemen there is considerable flexibility and adaptability in indigenous tribal procedures and decisions, more so than one usually finds in state justice systems, and decisions are restitutive rather than coercive. Furthermore, indigenous dispute mediation, where fines are shared by the entire community, is less costly than the formal legal system. On the other hand, there are concerns that traditional justice may perpetuate social hierarchies by favoring the powerful or discriminating against women (Corrin Care 2000; Kameri-Mbote 2005; Kollapen 2005; Tripp n.d.). In Yemen, as elsewhere, "local strongmen" may co-opt traditional mechanisms by using force in ways that would not have been permitted historically (Dempsey and Coburn 2010). Political scientists worry that resort to traditional justice may undermine state sovereignty.

In this article, I explore these issues as they apply to self-identified tribal communities in Yemen's Central Highlands through case studies of mediation that I collected during extensive fieldwork between 1978 and 2005 in al-Ahjur. ${ }^{1}$ Al-Ahjur is an agricultural community irrigated by mountain springs, about $34 \mathrm{~km} \mathrm{NW}$ of Sanaa. The vast majority of its population self-identifies as tribal ( $g a b \bar{a} ' i l$, sing. $g a b \bar{l} l \vec{l}$ ). The tribal population historically distinguished itself from an urban scholarly elite that includes descendants of the Prophet Muhammad (sāda, sing. sayyid) and from low-status service providers, such as musicians, butchers, and vegetable growers, with none of these groups

\footnotetext{
* The present contribution is based on a paper presented at the Institute for Social Anthropology (ISA) of the Austrian Academy of Sciences, October 7, 2010. An earlier version of this article was presented as "Mediating Culture: Customary Law in Yemen" at the Conference on Customary Law, Princeton University, May 2006. I thank Daniel M. Varisco, Frank H. Stewart, and Andre Gingrich for helpful comments on earlier drafts. The transliteration of Arabic terms and names follows that of the International Journal of Middle Eastern Studies, but reflects al-Ahjur's dialect. Thus, $q$ becomes $g$; and the vowel $u$ is pronounced as $i$. The exceptions are Sanaa and al-Ahjur, which follow formal usage.

${ }^{1}$ My warmest thanks go to the households of Mr. 'Abdallāh 'Abd al-Qādir and residents of al-Ahjur's villages who hosted me and patiently explained local customs. Fieldwork in al-Ahjur was funded by a National Science Foundation Grant for Improving Doctoral Dissertation Research and a Temple University Graduate Fellowship in 1978-79. My fieldwork in 1983 focused on local attitudes toward breastfeeding and fertility and was funded by a MEAward in Population and Development, The Population Council. My 2005 research on changes in dancing and tribal identity was funded by the American Institute of Yemeni Studies. Other research in Yemen was conducted in conjunction with a variety of consulting assignments. Additional information was gathered through interviews with Yemeni shaykhs and judges in September 2004 and November 2005, and several meetings with Yemeni social scientists and folklorists at the qāt chew of Muhammad Muhsin Al-'Amrī in 2005.
} 
defined as tribal. ${ }^{2}$ According to the dictates of customary law, those who are not locally defined as tribal are technically under tribal protection. After a brief introduction to customary law and the process of mediation, their application in rural Yemen, and disputes considered outside the jurisdiction of customary law, I will present seven case studies. Based on these cases, I discuss the importance of mediation and customary law to tribal identity. In conclusion, I ask if recourse to customary law in Yemen hinders national development.

\section{Customary law}

What is tribal customary law in Yemen? Known locally by various terms, including " $u r f$," "ahkām al-asläf," or "sinna (sunna)," it is a set of principles and rules that regulates the reciprocal obligations of tribesmen and tribal obligations towards people defined as weak. These may be tribesmen in vulnerable situations or members of the nontribal population (Adra 1983: 181; Dresch 1993: 117151, 59-62; Gingrich 1989a; Glaser 1993 (1884): 176). Customary law covers all behavior Yemenis define as social, including rules of hospitality and greeting behavior (Adra 1983). It is as much a code of conduct as it is a set of legal directives. Local distinctions between criminal behavior and infringements of etiquette are marked differently than those common in the West. Although Yemenis are fully capable of distinguishing between criminal behavior and simple rudeness, any behavior which infringes on the rights of others or which prevents others from discharging their responsibilities is considered a public matter, subject to the dictates of law. Customary law did not traditionally cover issues of marriage, divorce or inheritance, nor does it cover disputes between siblings or parents and their children. In practice this means: when I host a guest, I do so as a representative of my community. If, however, I cheat my sister or neglect my parents this behavior only reflects my unsavory personality, not the reputation of the wider group. Cases of misconduct within the family are often subject to criticism, but they are not usually formally mediated by outsiders.

In Yemen, formally mediated disputes are recorded in writing, so excellent sources are available on customary law documents, as well as the application of customary law in markets and intertribal conflict (Chelhod 1971, 1975; Dostal 1996, 2001; Dresch 1981, 1987, 1989, 1993, 2005, 2006; Gingrich 1989a; Glaser 1993 (1884): 5-6; Hartley 1961; Maktari 1971: Meissner 1980, 1986; Rathjens 1951; Rossi 1948; Serjeant 1951; Weir 2007). There is less published material, however, on the more mundane disputes of daily life (but see Adra 1983; Serjeant 1951, Part 2). The way these are resolved can tell us a great deal about the extent to which customary law is integrated into social life in Yemen and the extent to which it forms a "grammar" that informs social behavior (Baumann and Gingrich 2004).

\section{Mediation}

In almost all disputes, a middleman is sought to mediate or arbitrate. ${ }^{3} \mathrm{He}$ - mediators are usually men - may be a tribal leader or anyone with a good reputation. To begin the process, disputants turn their daggers over to the mediator. They may also turn in rifles, pistols or, in lesser disputes,

\footnotetext{
${ }^{2}$ These distinctions are currently blurring; intermarriage is beginning to occur across status boundaries, and the category "tribal" is becoming more inclusive (Adra 1993; author's field notes 2005). Even in the 1970s, however, status distinctions were understated in al-Ahjur and elsewhere in the Central Highlands. This is in contrast to urban communities and other rural regions in Yemen where intra-tribal relations as well as relations with the nontribal population are markedly hierarchical. See, for example, Bujra 1971; Chelhod 1970; Dostal 1984; Gerholm 1977; Gingrich 1989b; Hartley 1961; Ho 2006: 33-34.

${ }^{3}$ In minor cases, such as the ones discussed here, the mediators act as guarantors.
} 
watches. (Women who, in al-Ahjur, are not usually armed, offer watches, jewelry or cash.) With this gesture, known as 'adāla or 'adāl (equivalence), ${ }^{4}$ the disputants signal that they have submitted to litigation. The weapons and valuables are returned at the end of the proceedings.

The mediation process itself, in which each side presents its case, often appears informal. It takes

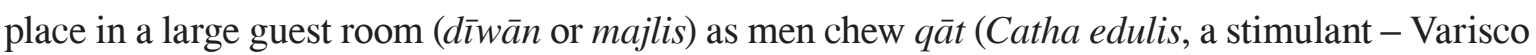
1986; Weir 1985), smoke water pipes or cigarettes, or sip hot drinks. Anyone who is interested attends the proceedings and takes part in the discussion. Voices may be raised, and opinions are given freely. ${ }^{5}$ At the same time, women meet to discuss the case in a nearby location. Children, who move easily between the men's and women's gatherings are marvelous messengers, providing verbatim accounts of the proceedings to both sides. In the evening, families discuss the case. The next day, men bring the opinions of their wives, mothers and sisters with them to the discussion. In passing judgment, the arbitrator is expected to follow consensus as well as legal precedent. Details of all disputes that are formally mediated are recorded in writing and stored with local leaders (shaykh) or the arbitrator.

Mediation as a process is not limited to formal dispute resolution but permeates all levels of conflict. Whenever a quarrel breaks out in public, observers will intercede voluntarily whether or not they are acquainted with the adversaries. The intervention of third parties is considered normal and desirable and has considerable preemptive value. If no one is around to witness a quarrel, disputants will shout loudly and angrily to attract attention. Such patterns are not new but were noted by Eduard Glaser in the $19^{\text {th }}$ century: "South Arabians of the same tribe, and particularly Hāshidī, start a conflict with words, and then they throw stones, and only reach for their rifles and jāmbiyyas [daggers] as a last resort" (Glaser 1993 (1884): 16).

\section{Case studies}

\subsection{Case 1: 'Alī and Hadī $1979^{6}$}

The first case involves a quarrel between two tribesmen, 'Alī and Hādī, on the land of a sayyid, who is respected for his leadership and mediation skills, and for whom 'Alī works as a wage laborer.' As they were irrigating adjacent lands ${ }^{8} \mathrm{Ha} d \overline{1}$ insulted 'Alī. 'Alī responded by striking Hādī on the shoulder with his shovel scoop. Hādī then grabbed 'Alī's dagger, nicked him in the hand, and ran away taking the dagger with him. In doing so, he left his share of water running freely. The angry 'Alī then diverted Hādì's share of the water onto the sayyid's fields, which he was irrigating at the time. This is 'Alī's version. Hādī's version is that he was hit on the shoulder from behind. He turned around to see 'Alī's knife poised ready to kill him. He then grabbed 'Alī's knife and fled. Later,

\footnotetext{
${ }^{4}$ Terms vary with region. Glaser 1984/1993: 6 recorded 'adāl or 'adāla. Elsewhere it is called 'idāl. In Taiz, it is called țarah (al-'Alīmī 1986: 40; al-'Alīmī and Dupret 2001).

${ }^{5}$ Caton (1990) discusses cases in which opinions, and sometimes decisions, are phrased in poetic form.

${ }^{6}$ This description is compiled from notes on the case taken by my husband, Daniel Varisco, who attended the mediation discussions (Varisco 1982: 349-55) and my own notes taken during the women's discussions of the case (Adra 1983: 201-03). Names of individuals and villages are pseudonyms.

${ }^{7} \mathrm{Sa} d a$, descendants of the Prophet Muhammad, are not defined as tribal in this part of Yemen and rarely act as tribal leaders (shaykh). In a departure from custom, this sayyid served as shaykh of several village clusters at a time when al-Ahjur's population could not agree on a tribal shaykh. He has since been replaced by a tribesman, son of a village shaykh.

${ }^{8}$ Hādī was irrigating his own plot of land, while 'Alī was irrigating land belonging to the sayyid.
} 
Hādī gave both his and 'Alī's daggers to the sayyid, thus requesting the sayyid to arbitrate the case and indicating his willingness to accept arbitration. (Technically, the sayyid is a plaintiff in this case because the dispute occurred on his land, - see Adra 1983: 185-87).

The next day in the afternoon a crowd of men gathered in the sayyid's majlis. 'Alī and Hādī appeared at the session unarmed. Also present were the shaykhs of 'Alī's and Hādī's villages and the muzayyin of Hādī's village. (Shaykhs are tribal leaders, and, in this area, also leaders of villages and other tribal sections. The muzayyin is a member of a protected social category of service-providers and not traditionally identified as tribal. In addition to his roles as musician, butcher, barber and circumciser, the muzayyin in al-Ahjur is a ritual expert. In major disputes, he is charged with dividing the animal sacrifice according to custom and receives the head, neck and skin of the animal for his services.) Both disputants had the opportunity to make their claims and hear the responses of their peers. The process appeared chaotic, as some men were shouting, while others urged calm.

A consensus eventually emerged: fighting, diverting water and grabbing a weapon were all examples of inappropriate behavior, but the disputants' most serious breach in the eyes of the community and the arbitrator was that they dishonored the sayyid by quarreling on his land. It was agreed that each man had wronged the other, both had wronged the sayyid, and neither could justify his actions. There was a further complication. The quarrel took place near the border where the lands of three villages meet. Residents of a small neighboring hamlet felt that an insult to the Sayyid's land was an affront to the entire community, and their village should partake of the settlement, since their honor also needed to be cleansed. The sayyid did not agree. ${ }^{9}$

Eventually, the sayyid wrote his decision on a small piece of paper. Both men together would contribute a cow for damages and to signal atonement (hijär). ${ }^{10}$ This would cost each of them approximately 1,500 YR (\$300 in 1979), a considerable sum for losing their tempers. ${ }^{11}$ (It was understood that their respective villages would help them pay this sum.) The cow would be butchered by the muzayyin, and the meat would be divided among Hādī, 'Alī and their respective villages. The sayyid would receive a portion of meat for his role as arbitrator and an additional portion as restitution because the struggle had occurred on his land. The sayyid would keep the daggers until the animal was sacrificed and the meat apportioned by the muzayyin. This decision was based on consensus in the majlis but ignored the neighboring hamlet's claim.

The cow was purchased at the next day's market and slaughtered. But as the muzayyin was carving it according to tradition, some men from the two neighboring villages grabbed meat for themselves. A loud argument and some scuffling ensued, and both the muzayyin and the herald (dawshān, also a protected client) were jostled and allegedly nicked with daggers.

Despite a heavy rain shower that afternoon, an angry crowd came to the sayyid's majlis to complain about the loss of the meat due to them. Seven men who had grabbed meat were required to hand over their daggers. Once again the conversation was heated. It was decided that although the residents of the two bordering villages felt they had been wronged by the sayyid's decision, they

\footnotetext{
${ }^{9}$ A history of problems between residents of this hamlet and the sayyid may have influenced his opinion.

${ }^{10}$ The hijār is not only a payment of damages. The slaughter of the animal signals an end to the quarrel, an atonement (Caton 1990: 73-74) or apology that presumes forgiveness (al-'Alīmī 1986: 40; Dresch 1981: 84 n. 11).

${ }^{11}$ In some regions of Yemen the cost of the animal is added to the cash restitution. In al-Ahjur it is subtracted from the total sum. Any additional cash restitution that is not spent on a sacrificial animal is divided as fees between the shaykh or other arbitrator, the guarantors and the witnesses.
} 
did not follow customary procedures to redress their grievances. Therefore, they had to abide by the decision. In addition, they were wrong to hurt members of protected minorities - the muzayyin and dawshān. ${ }^{12}$ Each of the two villages had to buy a cow to be distributed among all of the contenders. The decision was accepted and implemented, and there was no further escalation of this problem.

\subsection{Case 2: Retaliation 1978}

In Case 2, a man is fined heavily for attacking someone who had wronged him. Yahyā accidentally crushed a crate of tomatoes belonging to Șālih as he was backing up his truck. He offered to pay for the tomatoes, but Șālih refused, then took out his knife and stabbed Yahyā in the back as he walked away. Șālih, who initially had been the victim of Yahyā’s carelessness, had to pay Yahyāa reparations of 65,000 Y.R. ( $\$ 14,444$ in 1978) to cover his medical costs and a sacrifice of two cows. Not only did he try to take the law into his own hands when he should have registered a formal complaint, but he had stabbed a man in the back, a highly dishonorable act.

\subsection{Case 3: Shooting a qāt thief 2004}

One night in 2004 a man was caught trying to steal $q \bar{a} t$, a lucrative cash crop. When confronted by the guard, he pulled his dagger. In response, the guard shot and wounded the thief. The wounded man and his village brought a case against the guard, whose entire village was judged responsible for the costs of the thief's medical treatment. ${ }^{13}$

This case's judgment was controversial. It followed customary principles in that the party who suffers most in a dispute receives restitution, but the culprit-victim was, after all, a thief caught redhanded. Subsequently, all of the village shaykhs of al-Ahjur met and agreed on new rules to deal with $q \bar{a} t$ thieves: if a $q \bar{a} t$ thief is shot in the act and killed, the sum owed to his survivors is limited to 50,000 YR (c. \$255 in 2004) paid by the entire population (i.e., 24 villages) of al-Ahjur. This renders each household's contribution affordable. If the thief is hurt but not killed, a maximum of 250,000 YR is paid for his medical treatment, again by the entire population. If, however, the guard beats the thief with a stick and does not use his gun, the thief is owed no amends whatsoever.

4.4 Case 4: Involuntary homicide 2005

In spring 2005, a case of involuntary homicide shocked the community. A young man from Sanaa was visiting al-Ahjur. As he sat with two of his friends, he idly clicked a pistol that he did not realise was loaded. The gun went off, inadvertently shooting his friend in the neck, killing him instantly. The young man was horrified and immediately took responsibility. Police from the nearby town of Shibām were called, and took both surviving young men to prison.

The news spread fast, and that afternoon the men and women of the community met with the young men's parents who had been summoned from Sanaa. The culprit's family handed over weapons to guarantee their submission to mediation. No arbitrator was called, since all agreed it was a clear case of involuntary homicide, and no blood money (diya) was due. Still, the case had to be discussed. The culprit's family was held responsible for the costs of hospitality for all those who attended the discussion, for paying the victim's burial costs and for feeding the mourners. Because the police had been summoned, bringing the case to the government's attention, they

\footnotetext{
${ }^{12}$ The dawshān is the herald who often acts as public announcer in the market. He is entitled to a share of the meat. As service providers, both the muzayyin and dawshān (plural mazāyina and dawāshīn) are legally protected by the tribes. Harming them is considered a serious breach.

${ }^{13}$ Compare this with Glaser's description of rules governing theft (1993 (1884): 5-6).
} 
would eventually have to pay an additional 300-400,000 Yemeni riyals (\$1,530-\$2,041 in 2005) to the court in order to release the two young men from prison. (This is an illegal bribe but is so widespread that it was described to me wryly as the "government has to claim its due" -"alhuküma lāzim tākhudh haqqahä").) If, instead of relying on customary law, the family of the victim had decided to press charges in state court, I was told that it would have taken 8-10 years for the case to come to trial because the courts are overloaded.

\subsection{Case 5: Informal mediation 1979}

In 1979 a truck parked in a busy market town was being loaded with goods and people returning to their villages. Suddenly, two men standing on the back of this truck began shouting at each other. As I looked towards the direction of the sound, I noticed one of the men furtively looking around him. Clearly, his shouting was designed to attract attention. Men and women jumped onto the back of the truck trying to calm the adversaries. As soon as others joined him, the man whose face I could see began to make gestures as if to strike his adversary. The informal "mediators" immediately intervened by pulling him back. Another group was pulling his adversary back. It was an extraordinary piece of impromptu theater, choreographed to express anger safely (see fn. 19).

4.6 Marital disputes and their resolution

Marital disputes fall into a domain that straddles the personal, which is not usually covered by customary law, and the public, which is. The intimate relationship between husband and wife is defined as personal (Adra 1983: 227-33). On the other hand, a marriage is locally considered a form of alliance (Adra 1983: 175-77) with definite, agreed upon, mutual obligations of respect and reciprocal assistance between affines (Rossi 1948: 23). Any breach of these obligations that jeopardizes the affinal relationship is a public matter. Thus, third parties are often asked to intercede in marital disputes, but the husband is entirely responsible for restitution, instead of his entire village. This may be a consequence of the murky mix of personal and public that marriage entails, or because the frequency of marital disputes would make it impractical to involve the entire community with each case.

A wife who feels insulted by her husband or in-laws will leave "in protest" (hanaq) to her father's house or that of other close kinsman (see Würth 2005). ${ }^{14}$ Within three days her husband or his proxy should follow with a small gift as a token of apology. Often, this suffices to bring her back. If the two sides cannot agree, especially if the case is one of repeated insult, or if the husband has taken another wife, her kin may request divorce. ${ }^{15}$

4.7 Case 6: The cantankerous father-in-law 1978

Randa, whose husband was a migrant laborer in Saudi Arabia, lived alone with her ill-tempered father-in-law, Aḥsān, who constantly scolded her and made unreasonable demands on her time. She did not want a divorce, but life with her father-in-law had become unbearable. She went home in protest to her father, Muhammad, who decided to keep her at home at his own expense (iltazamh $\bar{a}$ ) until her husband returned. This left "Ahsān alone with no one to fetch water or cook for him.

He sought the help of mediators from Randa's village. One day, ten men, including the village shaykh, accompanied Aḥsān on a surprise visit to Muḥammad. These mediators first asked Muhammad to reiterate Randa's complaints. He did so, then added that his daughter had just cause

\footnotetext{
${ }^{14}$ Hanaq is the term used in Sanaa, al-Ahjur, and neighboring regions. Other terms are used for this practice elsewhere in Yemen and in other Arab countries.

${ }^{15} \mathrm{Few}$ women in al-Ahjur tolerate polygyny. If a husband remarries, his first wife is likely to leave him.
} 
(hijja) and that he would accept nothing less in restitution than the slaughter of a bull and 3,000 Yemeni riyals, bringing the total in dollars to approximately $\$ 1,550$ in 1978. (This was tantamount to saying he would not agree to return his daughter, since Ahsān could not possibly afford this sum.) The mediators protested that Ahsān had no way to collect this vast sum. They agreed that he should not continue his reprehensible behavior but argued that the sum requested was unreasonable. Muhammad remained unmoved; he would keep his daughter at home.

The mediators then removed their head coverings and placed them on Muhammad's lap in entreaty (jīhān). By doing so they were asking Muhammad to forgive ( $y a^{\prime} f \bar{l}$ ) Aḥsān on their honor. Muhammad had to give in; he could not continue to resist without dishonoring his guests. But he had made his point; it was only under the most extreme pressure that he forgave his adversary. Aḥsān could not insult his daughter again without also insulting the mediators. ${ }^{16}$

It was agreed that Ahsān would pay the still considerable sum of 1,000 YR (\$200) in reparations. Five hundred riyals would be given to Randa, with the remainder to be distributed equally among the mediators. Throughout this exchange, one of the mediators wrote down the proceedings and the decision. After Ahsān paid up, Randa returned to live with him. She bought a gold coin with her share of money and wore it as a pendant, a visual reminder to Ahsān that she could leave again if provoked. I saw Randa a few months later and asked about her home life. She replied that her father-in-law's behavior had improved.

\subsection{Case 7: The Protector and protégé (damìm or jār) 1983}

There are instances when a person feels it necessary to place himself or herself under the protection of another person (Dresch 1993: 60-1, 258; Rathjens 1951: 183). In this case an unhappy wife sought refuge with a man unrelated to her. Fāțima, whose husband had married a second wife, wanted a divorce, but her father refused to demand a divorce, and her husband also refused to grant her a divorce. ${ }^{17}$ She decided to seek the help of her father's brother in Sanaa. On her way she accepted a ride with a sayyid known to her who took her temporarily into his household as protégé. By taking responsibility for her, the sayyid was obliged to take an active part in the negotiations between the families concerned and to lend his support toward ameliorating her condition. ${ }^{18}$ To establish a damim relationship it was sufficient for Fatima to seek the sayyid's help, - she did not need to sacrifice an animal nor utter any prescribed formula. She was roundly criticised by her in-laws for riding in a car alone with the sayyid, thus risking her reputation. But ultimately her actions were justified both by customary law and the sayyid's reputation as someone who respects women's honor.

\section{Discussion}

These case studies demonstrate the extent to which legal process is integrated into daily life. All of them include some form of mediation by a third party, and all members of the community are expected to do their part in resolving disputes, either by restraining people from using force, participating in the mediation process, or sharing the costs and the benefits of restitution. ${ }^{19}$ This process allows

\footnotetext{
${ }^{16}$ See Dresch 1993: 50. Compare this with Stewart's discussion of jaahih (2003: 267).

${ }^{17}$ If the husband requests a divorce, he must pay his wife an agreed upon sum (mahr). If she and her family request a divorce, they must return the brideprice (shart ) to her husband.

${ }^{18}$ See Würth 2005: "During the 1970s [in Yemen] women in rural areas would also turn to local shaykhs or judges" (p. 304, n. 4). Compare also with Stewart: "In some areas, if the guardian is unwilling to help a woman against her husband, a notable may take her part" (Stewart 2006: 259).

${ }^{19}$ Similar principles apply to disputes that break out in markets: "If conflict breaks out in a market, a
} 
disputants to choose their own arbitrators, air their grievances and negotiate compromise without jeopardizing their autonomy. Customary law not only maintains peace among an armed population in a region of widely dispersed communities that are difficult of access, but it affirms, and the mediation process enacts, tribal values that prioritise obligations of mutual responsibility (Caton 1990).

Customary law also regulates cooperative activity. Projects that will benefit the entire community require the labor of at least one person from each household. A smaller project, such as cooking for a wedding, requires the help of any woman with kinship or affinal ties to the host's family. If a truck is stuck in the mud, anyone around must help lift it up. None of these situations require formal mediation, but they are very much a part of tribal customary law in Yemen.

I suggest that the principles of customary law form a "grammar" of tribal behavior as it is defined in Yemen (see Baumann and Gingrich 2004). Or, in performative terms, its enactment affirms and recreates tribal custom. In either case, principles underlying customary law generate a set of expectations and behaviors that includes the necessity to mediate disputes and to participate in their resolution. Tribal mediation processes reinforce a high value on cooperation while maintaining respect for autonomy. The flexibility built into legal processes reflects an appreciation for context. Mediation, cooperation, autonomy and flexibility all characterise the values that define tribal identity in Yemen (Adra 1983, 1985). These values are closely tied to local concepts of tribal honor, known in Yemen as gabyila. ${ }^{20}$ More than genealogy, occupation or even military prowess, tribal self-definition rests on principles of action, which include courage, community responsibility, hospitality, and hard work, as well as a respect for individual autonomy. Every conflict that is resolved through mediation, like every cooperative project, enacts tribalism as it is locally understood, and consequently affirms and recreates tribal values.

Like grammar in language, however, such rules are not absolute. They can be changed. The new rule governing $q \bar{a} t$ thieves was one of many changes to customary law recently implemented in the Central Highlands. Another set of new rules limits the bride price within particular communities, a radical departure from custom which did not deal with such issues. ${ }^{21}$

\subsection{Gender considerations}

I was surprised to discover women's participation in dispute resolution because I had been told that women played no role in tribal affairs. Similarly in Munebbih, in the far Northwest of Yemen, Gingrich (1997) found women actively taking part in mixed gender mediation, again in contradiction to formally stated principles. Rural women's active role in the community is related to an important urban/rural distinction in Yemen. In general, rural women participate in the local economy and are more mobile than urban women (compare with Chatty 1978). By local definition, an urban community is one in which women are more secluded than rural women. Although urban women enjoy greater prestige in a society that values female seclusion, they also have a reduced voice in community affairs (Adra 1983, 2007, 2008). ${ }^{22}$ Cases 6 and 7 point to safety nets that benefit

third party who is present is obliged to intervene and make peace, regardless of his relation, if any, to those at odds. If he takes sides and joins the squabble, then he too is guilty of a breach of the marketpeace" (Dresch 1990: 65).

${ }^{20}$ Or qabwala in the South.

${ }^{21}$ In the mid-1970s President Ibrahim al-Ḥamdī attempted to curb excessive bride price, but this was a state and not a tribal initiative.

${ }^{22}$ Many rural women refuse to join their husbands in the city because they do not want to give up the mobil- 
married women. These examples contradict existing stereotypes of women's lives in the region. They also point to the heterogeneity of women's status in the Arab region and within Yemen. ${ }^{23}$

\subsection{Implications to development}

I hope to have provided evidence that tribal customary law in Yemen is a sophisticated legal system, grounded in mediation and conflict resolution. For centuries, and probably millennia, Yemeni tribes have utilised techniques to resolve conflict that are today considered "cutting edge" in developed countries. But is a reliance on customary law detrimental to development and state formation, or can it facilitate these processes? Concerns about the continued utilisation of indigenous justice usually revolve around its compatibility with human rights principles, local development, state sovereignty and, in Muslim majority countries, its compatibility with Islamic law. Each of these concerns will be addressed below.

5.3 Human rights concerns: Implications to the rights of women and socially excluded groups

Cases 6 and 7 highlight aspects of customary law that protect the rights of married women. On the other hand, women are largely dependent on men's support, usually of their kin. When a woman's kin do not choose to support her, her options are limited as we saw in Case 7. But is the situation any better in state courts? Although state courts, like customary mediation, aim to reunite estranged spouses, they tend largely to support the husband's claims over the wife's (Würth 2003).

Likewise, customary law specifies the protection of socially excluded groups, as we saw when the muzayyin and dawshān were hurt by tribesmen in Case 1. This is not to say that they always, or even usually, receive equal treatment by arbitrators and others. Nor do they necessarily fare better with the state justice system. The Yemeni constitution bans traditional social stratification, and many members of formerly excluded groups have accumulated wealth and climbed the social ladder to become professionals and leaders in urban contexts. There are recent cases of members of excluded groups being elected as local shaykhs, thus signaling their acceptance as tribal (Adra field notes, 2005). ${ }^{24}$ Nevertheless, the poor and excluded do not have easy access to state courts, especially since sizeable (illegal) bribes are usually required to bring a case to court. As is the case elsewhere, the judicial system may "further rather than circumscribe existing relations of authority (...) [or] serve dominant groups and classes by obscuring inequality" (Brown 1997: 11-12). Moreover, court procedures are extremely slow in Yemen, and [often] family issues are considered too private to discuss in court. Thus the consensus among urban scholars as well as rural arbitrators is that arbitration is the better alternative, especially since it allows the disputing parties to choose their own judges (al-Zwaini 2005: 315, quoting al-Marwanī). In short, although customary law may not be ideal for women and excluded groups, state courts are not more consistent in protecting their rights.

5.4 Compatibility of customary law with state sovereignty

\subsubsection{Historical background}

As is the case elsewhere in the Middle East and North Africa, state-tribe relations, currently and in the past, reflect both an urban-rural divide and tensions that have existed in this region prior to start of

ity that rural living affords them. This includes the wives of shaykhs who own impressive villas in Sanaa.

${ }^{23}$ One example, among many, is the stark contrast between the way women are treated in the Yemeni highlands and their apparent treatment among the Ahaywāt Bedouin of the Sinai, although underlying principles are similar in both societies (Stewart 1991).

${ }^{24}$ See Adra (2006) for an analysis of changing categories of social exclusion in Yemen. 
the Islamic era in the $7^{\text {th }}$ century. Power struggles emerged as urban states attempted to extend their sovereignty over neighboring tribes. Tribal leaders were frequently co-opted by state governments, as is the case currently in Yemen. On their part, tribes have raided towns during droughts, creating a legacy of hostility to tribalism. Throughout, tribes and states have been mutually dependent economically and politically. Historically, rural tribes provided military protection and food, while towns provided markets, religious guidance and mediators. Today in Yemen, we see a replica of historic and regional tensions. Although dependence on local agricultural products has diminished considerably, the army is largely constituted of men who self-identify as tribal. Attitudes of urban elites toward tribes, in the region as well as in Yemen, have been ambivalent, combining disdain for what they perceive as uncouth rural lifestyles with romantic views of tribal ethics and hard work. Urban elites, influenced by $19^{\text {th }}$ century European models of nationalism, yearn for homogeneity. They, like many Western political scientists and journalists, assume rather rigid, programmed paths to national development and blame hurdles on the "uneducated, violent tribes."

\subsubsection{Models of the state}

Until very recently, political scientists appeared wedded to visions of nation-state that mirrored Euro-American models. Requirements for sustainable statehood were thought to include liberalism, secularism, the nuclear family, and above all, state monopoly over the use of violence. Thus, one finds in Sarah Phillips' otherwise perceptive study of Yemeni patronage systems, a serious concern over what appear to be ambiguous boundaries between state and tribal sovereignty: "Yemen must deal with the question of what the legitimate sources of political authority are. In some parts of the country, there is still ambiguity over who - the state or the local tribe - exercises rightful control over territory and natural resources, as well as over who has the "right" to use violence" (2008: 90). To Phillips, tribal autonomy presents serious hurdles to state sovereignty, despite a history of the coexistence of tribal and state institutions. It is clear that current levels of patronage in Yemen are not economically or politically sustainable, but is the problem due to tribal customary law or to the regime's interest in maintaining its own power?

Clifford Geertz (2004) and Lisa Wedeen (2008) both argue for more fluid definitions and expectations of the conditions necessary to sustain statehood and democracy. In her study of urban $q \bar{a} t$ chews in Yemen, Wedeen argues that they are, "democratic in substantive representational terms (...) because they facilitate a kind of political participation (...) promote citizen awareness, and produce subjects who critically debate political issues (...). They are the site for the performance of citizenship" (Wedeen 2008: 119-20). She notes that even elections known to be fraudulent are still effective in generating popular participation (2008: 75). She concludes that distinctions need to be made between democratic and liberal values (2008: 105) and that democracy should not be conflated with order (2008: 220).

Wedeen, however, ignores alternative public spheres in Yemen, particularly those perceived by urban elites as subaltern or marginal: urban working classes, hereditary service providers, and self-identified tribes. The latter constitute the vast majority of the rural population. Moreover, new immigrants to Yemen's cities who maintain family homes in villages continue to identify as tribal. Had she conducted field research in rural contexts, ${ }^{25}$ she would have realised that urban $q \bar{a} t$ chews are outgrowths of the traditional majlis, itself an enactment of the open discussion

${ }^{25}$ By rural contexts, I mean villages. Communities described as rural by Wedeen are locally defined as towns. They are only considered rural by members of the urban elite and expatriates. 
of governance issues that characterises tribal society in Yemen and on the Arabian Peninsula. The incipient participatory democracy that Wedeen describes is a replica of tribal discussion and exchange. Ignoring those vast spheres of popular interaction and negotiation might result in seriously underestimating the formation of public opinion at the grass root levels, manifesting themselves in seemingly abrupt upheavals such as those of early 2011.

Walter Dostal, like Geertz (2004) and Wedeen (2008), cautions against the mechanical application of Western models of state formation to nations that do not share the political trajectory of European or American history. In an interview published in Current Anthropology, Dostal presents a case in support of what he calls "tribal democracy":

Two years ago I met a Bedouin shaykh who had once suggested, in an Iraqi assembly, turning to elements of tribal democracy and developing their own democracy from there. But of course, this is not the case in what is going on there today. One instantly wants a Western type of democracy, and it does not work. In many Arab contexts, tribes and tribal relations will remain the authoritative social entities, even within drastic social changes and because of them (Gingrich and Haas 2007: 431).

Like Dostal, I suggest that it may well be possible to sustain a modern nation that incorporates positive aspects of tribal custom within a sovereign state. Certainly, the extended discussion of community issues during conflict mediation, and especially the participation of children as messengers, has promoted the development of an articulate population ready to participate in the process of national development. This is particularly notable given Yemen's very high illiteracy rates, - over $60 \%$ in rural areas.

\subsection{Development today}

The case studies of mediation discussed above underscore the importance of reciprocal obligations in tribal social life. I have written elsewhere that Yemeni tribes and tribal segments are essentially cooperative units that can mobilise easily to perform tasks deemed important to the community, and that a combination of cooperative action and respect for individual autonomy characterises tribal customary law in Yemen (Adra 1983). This combination appears to have facilitated local development. Schools, mosques, health centers, feeder roads to villages, wells and cisterns have all been constructed through customary processes (Carapico 1998; Varisco and Adra 1984). Clearly then, customary law per se does not pose a threat to local development in Yemen, but does it threaten state sovereignty?

Perhaps most important is that tribal customary law is not necessarily at odds with state institutions. The Law of Arbitration of 1992 recognizes tribal arbitration as legally binding if both parties willingly agree to submit to it before litigation begins. Judges and government officials, including the President, have mediated intertribal disputes.

One concern is that of potential conflict of allegiance between the tribe and the state. This does not appear to be a problem in Yemen. As Lisa Wedeen writes, even in the diverse [tribal] North, "many inhabitants (...) actively support the president, even when they do not have to" (2008: 77). I have noted fervent nationalist feelings among the tribal populations with whom I conducted field research (Adra 1993). Nationalism is promoted by the current regime through the media (Adra 1996) and the school curriculum. By repeatedly pairing tribalism with nationalism, President Șālih counteracts potential conflicts of allegiance between tribe and state (Adra 1993). Under some conditions, tribalism and nationalism may reinforce each other. From a tribal perspective, it may be 
that the nation is conceived of as a segment - or cooperative unit (Adra 1983) - larger than the tribe rather than a separate entity that conflicts with tribal divisions. On the other hand, a population that is accustomed to articulating its complaints may not necessarily support all national projects, as has been made evident in the popular demonstrations of January 2011.

\subsection{Hurdles to development in Yemen}

There remain significant hurdles to development in tribal Yemen, including uncontrolled warfare in the North and South and the misuse of power by a few powerful shaykhs. Intellectuals and journalists often blame an undefined "tribalism" for these problems, Yet, as I have shown, these problems signify a breakdown of customary law, not its ultimate realisation. They are examples of what Baumann and Gingrich might dub, "anti-grammar" (2004) a term that describes situations of uncontrolled violence which threaten the survival of the society itself (see also Dresch 2000: 198).

Blood feud, the most problematic of tribal institutions, does constitute a serious hurdle to development. Yet in Yemen, blood feud is historically limited to arid regions where land is not privately owned, and which today lack services, including roads, schools and health centers. Yemenis have explained to me that people who have property to protect have too much to lose to risk engaging in blood feud. ${ }^{26}$ It appears, then, that pragmatic concerns are more likely to perpetuate blood feud than some elusive concept of honor, as is usually assumed.

Another significant hurdle to development in Yemen is overtly anti-tribal, - the influence of Wahhabism, and other conservative politicised interpretations of Islam, which are gaining influence through schools, charities, and mosques. Proponents of this view denounce tribalism as un-Islamic and target women's traditional rights and safety nets. Despite hostile discourse between some proponents of Islamic law and custom, these two legal systems have historically borrowed from each other and continue to do so. Major differences include personal status laws, specifically women's rights to divorce (see Cases 6 and 7 above; Würth 2005) and women's inheritance. Among tribes, most women forego their rights to inherit land in return for the promise of lifelong support from their brothers. But not all women do so: some families designate land in the names of daughters, and some women insist on managing their own property. In all cases, customary law requires annual gifts to a married woman from her kin. In practice, both customary and Islamic law assume a woman's dependence on her male kin. In sum, none of these hurdles to development are attributable to "tribalism" per se.

\section{Conclusion}

Tribes and states have coexisted in the region for millennia (Khoury and Kostiner 1990). While not all aspects of tribalism are positive, tribal cooperative mechanisms and methods of resolving conflict through mediation are exemplary and currently being emulated in developed countries with robust state courts. Following customary rules, communities form an indigenous "civil society" that can, and has, realised development projects such as the building of roads, schools and health centers and the cleaning of cisterns. Such activity not only challenges stereotypes but facilitates development, especially in the absence of a strong state.

With the establishment of a republican government in the 1960s and the major socio-economic changes that followed, including a monetised economy, rapid urbanisation, a decline in agriculture

\footnotetext{
${ }^{26}$ I thank Dr. Muhammad Jarhoum for first bringing this to my attention.
} 
and artisanal fishing, and a blurring of status differences, most observers expected to see a decline in tribal identification in Yemen's highlands. Instead, there has been a reanimation of tribal mechanisms throughout the Central Highlands. Serge Cleuziou and Maurizio Tosi (2007), archaeologists who have worked in Oman, argue that the data shows alliances and cooperative systems operative in the region as early as the $5^{\text {th }}$ millennium. Recurring adaptation to ecological change and population growth changed the forms of alliance but did not establish hierarchical systems. If these data and interpretations are sound, then surely indigenous systems that juxtapose cooperation with autonomy have a good chance of continuing to adapt into the $21^{\text {st }}$ century.

- NAJWA ADRA is a cultural anthropologist with long-term experience in research and consulting in Yemen. Her main research interest are tribalism and customary law in Yemen, gender, and anthropology of dance. Her most recent publications include "Literacy through Poetry/Heritage" (Anthropology News, 2010) and "Steps to an Ethnography of Dance" (in: Mary Strong and L. Wilder (eds.), Viewpoints: Visual Anthropologists at Work, 2009). 


\section{Literature}

Adra, Najwa. 1983. Qabyala: The Tribal Concept in the Central Highlands of the Yemen Arab Republic. Ph.D. dissertation in Anthropology, Temple University.

- 1985. The Tribal Concept in the Central Highlands of the Yemen Arab Republic, in: Hopkins, N.S. and S. E. Ibrahim (eds.), Arab Society: Social Science Perspectives. Cairo: The American University of Cairo Press, 275-85.

- 1993. Tribal Dancing and Yemeni Nationalism: Steps to Unity, Revue du Monde Musulmane et de la Méditerranée 67(1): 161-68. (Translated into Arabic in: Al-Yaman Kama Yarah al-Akhar, L. Taminian and A. al-Auj (eds.), 1997, Sanaa: American Institute for Yemeni Studies.)

- 1996. The 'Other' as Viewer: Reception of Western and Arab Televised Representations in Rural Yemen, in: Crawford, P.I. and S.B. Hafsteinsson (eds.), The Construction of the Viewer: Media Ethnography and the Anthropology of Audiences. Højbjerg: Intervention Press, 255-69.

- 2006. Social Exclusion Analysis - Yemen. Unpublished report prepared for DFID and the World Bank.

- 2007. Economic: Agricultural Labor. Yemen, in: Joseph, Suad (ed.), Encyclopedia of Women and Islamic Cultures, vol. 4, Leiden: Brill, 136-37.

- 2008. Learning through Heritage, Literacy through Poetry, Adult Education and Development 70. Available online in English, French and Spanish: http://www.dvv-international.de/index. php?article_id=731\&clang=1.

al-'Alīmī, Rashād. 1986. Al-quḍā’ al-qabalī fī al-mujtama' al-yamanī. Sanaa: Dār al-wādī li-1nashr wa-l-tawzī'.

al-'Alīmī, Rashād and Baudoin Dupret. 2001. Le droit coutumier dans la société yéménite: nature et developpement. Chroniques Yéménites. Electronic document http://cy.revues.org/document71. html, accessed January 12, 2004.

Baumann, Gerd, and Andre Gingrich (eds.). 2004. Grammars of Identity/Alterity: A Structural Approach. New York: Berghahn.

Brown, Nathan J. 1997. The Rule of Law in the Arab World: Courts in Egypt and the Gulf. Cambridge: Cambridge University Press.

Bujra, Abdalla S. 1971. The Politics of Stratification. A Study of Political Change in a South Arabian Town. Oxford: Clarendon Press.

Carapico, Sheila. 1998. Civil Society in Yemen: The Political Economy of Activism in Modern Arabia. Cambridge: Cambridge University Press.

Caton, Steven. 1990. "Peaks of Yemen I Summon": Poetry as Cultural Practice in a North Yemeni Tribe. Berkeley: University of California Press.

Chatty, Dawn. 1978. Changing Sex Roles in Bedouin Society in Syria and Lebanon, in: Beck, Louis and Nikki Keddi (eds.), Women in the Muslim World. Cambridge: Harvard University Press, 399-415.

Chelhod, Joseph. 1970. L’Organisation sociale au Yémen, L’Ethnographie 64: 61-86.

- 1971. Le Droit Coutumier Yéménite, in: Chelhod, J., Le Droit dans la Société Bédouine. Paris: Librairie Marcel Rivière et Cie, 427-32.

— 1975. La Société Yéménite et le Droit, L’Homme 15(2): 67-86.

Chirayath, Leila, Caroline Sage, and Michael Woolcock n.d., Customary Law and Policy Reform: 
Engaging with the Plurality of Justice Systems Background, Paper for the World Development Report 2006: Equity and Development.

Cleuziou, Serge, and Maurizio Tosi. 2007. In the Shadow of the Ancestors: The Prehistoric Foundations of the Early Arabian Civilization in Oman. Sultanate of Oman: Ministry of Heritage and Culture.

Corrin Care, Jennifer. 2000. Customary law and women's rights in Solomon Islands, Development Bulletin 51: 20-22.

Dempsey, John, and N. Coburn. 2010. Traditional Dispute Resolution and Stability in Afghanistan, United States Institute of Peace. Peacebrief 10. Electronic document, www.usip.org.

Dimitrijevic, Vojin. 2006. Customary Law as an Instrument for the Protection of Human Rights, Working Papers, ISPI (Istituto per gli Studi di Politica Internazionale).

Dostal, Walter. 1984. Socio-Economic Formations and Multiple Evolution, in: Dostal, W. (ed.), On Social Evolution: Contributions to Anthropological Concepts. Proceedings of the Symposium Held on the Occasion of the 50th Anniversary of the Wiener Institut für Völkerkunde in Vienna, 12-16 December 1979. Vienna: Verlag Ferdinand Berger und Söhne.

- 1996. The Special Features of the Yemeni Weekly Market System: An Attempt at an Anthropological Interpretation, in: Rex Smith, G., J. R. Smart, and B. R. Pridham (eds.), New Arabian Studies 3. Exeter: University of Exeter Press, 50-57.

- 2001. Structure et principes du droit coutumier tribal yéménite. Interprétation anthropologique, in: Dostal, W. (ed.), L'univers du Mashreq. Essais d'anthropologie. Paris: Editions de la Maison des sciences de l'homme, 161-212.

Dresch, Paul. 1981. The Several Peaces of Yemeni Tribes, Journal of the Anthropological Society of Oxford,12(2): 73-86.

— 1987. Episodes in a Dispute between Yemeni Tribes, Der Islam 64: 68-86.

- 1989. Keeping the Imam's Peace: A Response to Tribal Disorder in the Late 1950s, Peuples Méditerranéens 46: 77-95.

- 1990. Guaranty of the Market at Huth, in: Serjeant, R.N. and R. L. Bidwell (eds.), Arabian Studies. Cambridge: Cambridge University Press, 63-92.

- 1993. Tribes, Government, and History in Yemen. Oxford: Clarendon Press.

— 2000. A History of Modern Yemen. Cambridge: Cambridge University Press.

- 2006. The Rules of Barat. Tribal Documents from Yemen. Sanaa, Yemen: Centre Français d'Archéologie et de Sciences Socials and Deutsches Archäologisches Institut.

Geertz, Clifford. 2004. What Is a State If It Is Not a Sovereign? Current Anthropology 45(5): 577-93.

Gerholm, Tomas. 1977. Market, Mosque and Mafraj. Social Inequality in a Yemeni Town. Stockholm: University of Stockholm.

Gingrich, Andre. 1989a. The Guest Meal among the Munebbih: Some Considerations on Tradition and Change in 'aish wa milh in Northwestern Yemen, Peuples méditerranéens 46: 129-149.

- 1989b. How the Chiefs' Daughters Marry. Tribes, Marriage Patterns and Hierarchies in Northwest-Yemen, in: Gingrich, Andre, Siegfried and Sylvia Haas, and Gabriele Paleczek (eds.), Kinship, Social Change and Evolution. Proceedings of a Symposium held in honour of W. Dostal. Wiener Beiträge zur Ethnologie und Anthropologie Bd. 5, 75-85.

— 1993. Tribes and Rulers in Northern Yemen, in: Gingrich, Andre, Sylvia Haas, Gabriele Pale- 
czek, and Thomas Fillitz (eds.), Studies in Oriental Culture and History. Festschrift for Walter Dostal. Frankurt am Main: Peter Lang, 253-80.

— 1997. Inside an Exhausted Community, in: Howell, Signe (ed.), The Ethnography of Moralities. London: Routledge, 152-177.

Gingrich, Andre, and Sylvia Haas. 2007. An Interview with Walter Dostal, Current Anthropology 48(3): 429-37.

Glaser, Eduard. 1993 (1884). My Journey through Arhạa and Hāshid (Translation of Meine Reise durch Arhab und Hāschid). Petermanns Mitteilungen 30: 170-83, 204-13.

Hartley, John G. 1961. The Political Organization of an Arab Tribe of the Hadhramaut. Doctoral Dissertation, London School of Economics.

Ho, Engseng 2006. The Graves of Tarim: Genealogy and Mobility across the Indian Ocean. Berkeley: University of California Press.

Kameri-Mbote, Patricia. 2005. Inheritance, Laws and Practices affecting Kenyan Women, in: Mwagiru, Makumi (ed.), African Regional Security in the Age of Globalisation. Nairobi: Heinrich Böll Foundation. Available in pdf: http://www.ielrc.org/content/a0502.pdf.

Khoury, Philip S., and Joseph Kostiner (eds.). 1990. Tribes and State Formation in the Middle East. Berkeley: University of California Press.

Kollapen, Jody. 2005. Identity and Democracy: Building Multicultural Democracies. Presentation at the Forum on Global Development convened by the UNDP and the French Ministry of Foreign Affairs and held in Paris, France from the 17th to the 19th January Johannesburg.

Maktari, A. M. A. 1971. Water Rights and Irrigation Practices in Lahj. A Study of the Application of Customary and Shari' 'ah Law in South-West Arabia. Cambridge: Cambridge University Press.

Meissner, Jeffrey. 1980. Customary and Islamic Law in North Yemen. Paper presented at the Meetings of the American Anthropological Association, Washington, DC.

- 1986. Tribes at the Core: Legitimacy, Structure and Power in Zaydi Yemen. Doctoral Dissertation in Anthropology, Columbia University.

Phillips, Sarah. 2008. Yemen's Democracy Experiment in Regional Perspective: Patronage and Pluralized Authoritarianism. New York: Palgrave Macmillan.

Rathjens, Carl. 1951. Ṭāghūt gegen Scherī‘a, Jahrbuch des Linden-Museums 1: 172-87.

Rossi, Ettore. 1948. Il Diritto Consuetudinario delle Tribu Arabe del Yemen, Rivista degli Studi Orientale 23: 1-36.

Serjeant, R. B. 1951. Two Tribal Law Cases (Documents) (Wāhīdī Sultanate, South-West Arabia), Journal of the Royal Asiatic Society 33-47: 156-69.

Stewart, Frank. 1991. The Woman, Her Guardian, and Her Husband in the Law of the Sinai Bedouin, Arabica 38: 102-29.

- 2003. The Contract with Surety in Bedouin Customary Law, UCLA Journal of Islamic and Near Eastern Law 2(2): 163-280.

Syria-News.com = 'Aqd al-rāya wa ḥalihā...sīrianiūs tanfarị̣ bitaghtiyat șulh li'ashā’ir al-'arab yanhī nizā'an damawiyyan. Electronic document: http://syria-news.com/readnews.php?sy_ seq=119699, accessed August 14, 2010.

Tripp, Aili Mari, n.d. Women's Movements, Customary Law, and Land Rights in Africa: The Case of Uganda. African Studies Quarterly. Electronic document: http://www.africa.ufl.edu/asq/v7/ v7i4a1.htm. 
UNDP = Rule of Law, Informal Justice. Electronic document, http://www.unrol.org/article. aspx?article_id=30 accessed September 19, 2010.

Varisco, Daniel Martin. 1983. The Adaptive Dynamics of Water Allocation in al-Ahjur, Yemen Arab Republic. Doctoral Dissertation in Anthropology, University of Pennsylvania.

— 1986. On the Meaning of Chewing: The Significance of Qāt (Catha Edulis) in the Yemen Arab Republic, International Journal of Middle East Studies 18: 1-13.

Varisco, Daniel Martin, and Najwa Adra. 1984. Affluence and the Concept of the Tribe in the Central Highlands of the Yemen Arab Republic, in: Salisbury, Richard Frank and Elisabeth Tooker (eds.), Affluence and Cultural Survival, Washington, DC: The American Ethnological Society, 134-49.

Weir, Shelagh. 1985. Qāt in Yemen: Consumption and Social Change. London: British Museum Publications.

- 2007. A Tribal Order: Politics and Law in the Mountains of Yemen. Austin, TX: University of Texas Press.

Würth, Anna. 2005. Mobilizing Islam and Custom Against Statutory Reform: Bayt al-Ṭā'a in Yemen, in: Dupret, Baudouin and François Burgat (eds.), Le Shaykh et le Procureur. Systèmes Coutumiers et Pratiques Juridiques au Yémen et en Égypte. Egypte/Monde Arabe, 289-308.

al-Zwaini, Laila. 2005. Mediating between Custom and Code: Dār al-Salām, an NGO for Tribal Arbitration in San'a', in: Dupret, Baudouin and François Burgat (eds.), Le Shaykh et le Procureur. Systèmes Coutumiers et Pratiques Juridiques au Yémen et en Égypte. Egypte/Monde Arabe, 323-35. 